\title{
Papillary Serous Cystadenocarcinoma
}

National Cancer Institute

\section{Source}

National Cancer Institute. Papillary Serous Cystadenocarcinoma. NCI Thesaurus. Code C8377.

A malignant cystic serous epithelial neoplasm characterized by the presence of malignant glandular epithelial cells forming papillary structures. Stromal invasion is present. 